\title{
Clinical Significance of Cervical Low-Grade Squamous Intraepithelial Lesions: 8 Years' Experience
}

\author{
Önder Sakin, Kadir Güzelmeriç, Bülent Kars, Orhan Ünal
}

\author{
Department of Obstetrics and \\ Gynecology Clinic, Kartal Dr. Lütfi \\ Kırdar Training and Research \\ Hospital, Istanbul, Turkey \\ Submitted: 25.06 .2015 \\ Accepted: 26.06.2015 \\ Correspondence: Önder Sakin \\ Dr. Lütfi Kırdar Kartal Eğit.ve Araş. \\ Hast., Kadın Hastalıkları ve Doğum \\ Kliniği, Kartal, İstanbul, Turkey \\ E-mail: sakin-onder@hotmail.com \\ Keywords: Colposcopy; \\ low-grade squamous \\ intraepithelial lesions; smear.
}

\begin{abstract}
Objective: The aim of the present study was to evaluate the follow-up results in patients who initially had cervical smear results showing low-grade squamous intraepithelial lesions (LSIL) in order to determine their histologic outcomes and develop a management guideline.
\end{abstract}

Methods: A total of 240 non-pregnant women with LSIL in their cervical smears were evaluated with colposcopy, and colposcopically directed biopsies and endocervical sampling were done as indicated. Patients had follow-up smears every 3 to 4 months.

Results: Of the 240 patients with LSIL, 108 patients (62.8\%) were classified as having cervical intraepithelial neoplasia I (CIN I), 28 (16.3\%) cases had CIN 2, I 2 patients (6.8\%) had CIN 3, and 4 patients (2.3\%) were diagnosed with invasive cervical carcinoma. At I2-month follow-up, persistence was observed in $38(22 \%)$ cases, and progression to high-grade dysplasia was seen in 16 (9\%) cases. Regression to normal smear was observed in 118 cases $(68 \%)$.

Conclusion: Since cervical minor abnormalities can change to low-grade lesions, high-grade lesions, or even cervical carcinoma, colposcopy was found to be an appropriate method for a correct diagnosis. Colposcopy in combination with smear was the ideal approach during follow-up.

\section{INTRODUCTION}

Low-grade squamous intraepithelial lesions (LSIL) are an abnormal test result frequently encountered in cervical smears. ${ }^{[1]}$ Despite many studies and research having been conducted for a long time, there is no consensus among clinicians regarding the evaluation of these smears. ${ }^{[2]} \mathrm{Qu}-$ ite diverse diagnosis, treatment, and follow-up algorithms have been put forward for patients with LSIL. These differences in follow-up can lead to many unwanted results.

Primarily, it may cause unnecessary and unreasonable anxiety in patients. Physicians face various questions and complications, including an obligation to make a fast diagnosis, yet excessive intervention and overtreatment that can include colposcopic examination, cervical biopsy or biopsies, Human papillomavirus (HPV) tests and excisional surgery often only adds to the burden of both clinician and patient. ${ }^{[3]}$ In addition, cases of carcinoma can be mis- sed due to varying nature of diagnostic criteria in smear examinations, significantly high rate of false positives, significantly high rate of preneoplastic changes under cells with unknown importance to cytological examination, and follow-ups that are carried out with only cytological examination, colposcopic imaging or macroscopic imaging. ${ }^{[4]}$

The present study sought to determine the significance of minor cytological abnormalities by clinically evaluating 8 years of LSIL-diagnosed smears from the hospital.

\section{MATERIAL AND METHODS}

Of all the patients from obstetrics and gynecology clinic of the hospital over 8 years, 240 non-pregnant women with LSIL cervical smear result according to Bethesda System criteria were taken under review. All patients had colposcopy, biopsy samples were taken from those with positive signs (e.g., punctuation, mosaic image, acetowhite area, 
lugol-free area, atypical vascularization), and endocervical curettage was performed if necessary. All patients were called for follow-up examination at 3-month intervals. Smear was performed again and biopsy sample collected during repeat colposcopy, if necessary. Histopathological results were compared to LSIL cytologies, and diagnoses were classified according to cervical intraepithelial neoplasia (CIN) stage: $\mathrm{CIN} \mathrm{I}, \mathrm{CIN} \mathrm{2,} \mathrm{or} \mathrm{CIN} \mathrm{3,} \mathrm{and} \mathrm{invasive}$ carcinoma. The sensitivity of the method was tested by comparing colposcopic findings to histological diagnoses.

\section{RESULTS}

The age of patients with LSIL ranged between 19 and 57 years. Only $5 \%$ of patients were in the age group of 25 and under. Biopsy samples were taken during colposcopy from $71.7 \%$ of patients (Table I).

Histological distribution of 172 patients with LSIL cytology for whom biopsies were performed was as follows: II.6\% chronic cervicitis, $62.8 \%$ CIN I, $16.3 \%$ CIN 2, 6.8\% $\mathrm{CIN} 3$ and $2.3 \%$ invasive cervical cancer. When $\mathrm{CIN}$ was assessed in terms of age distribution, it was seen that $\mathrm{CIN}$ was more commonly observed in premenopausal patients between 25 and 56. On colposcopic examination, dense acetowhite epithelium, mosaicism, punctuation, or atypical vascularization were observed in $71.7 \%$ of the patients with LSIL. Biopsies were performed for all of these patients. CIN was revealed histologically in $85.9 \%$ of patients with LSIL and invasive carcinoma in $2.3 \%$ of the patients (Table 2). Accordingly, the sensitivity of colposcopy in this study was determined to be $100 \%$.

All patients were called for smear follow-up at 3-month intervals (mean: 9 months). In LSIL cytologies during followup, persistence was seen in $22 \%$ ( $n=38$ ) of cases, and progression to $\mathrm{CIN} 2$ was detected in $9 \%(n=16)$. Regression in LSIL smear pathologies took place in $68 \%(n=118)$ of patients (Table 3).

\section{DISCUSSION}

As a result of joint research with 38 participants representing 14 countries, Scheungraber et al. reported that LSIL treatments are diverse and invasive, patients are generally young and want to conceive, and that a coordinated effort is needed to develop an applicable algorithm to prevent overtreatment. ${ }^{[l]}$

LSIL is still the most frequently encountered anomaly in smear examinations, seen in $1.5 \%$ to $1.8 \%$ of total smears. Kaygusuz et al. analyzed 37884 results of cervical smear and 153 biopsy results and determined LSIL rate to be $0.15 \% .^{[5]}$ Yalti et al. examined 28469 smear results and detected $67 \mathrm{LSIL}$ cases $(0.23 \%) .{ }^{[6]}$

There are some concerns regarding the accuracy of smear examinations. As a result of studies conducted on cytological diagnostic values, it has been established that detection sensitivity of cytology for histologically proven LSIL ranges between $38 \%$ and $89 \%$. The specificity of cytology in detecting LSIL or high-grade squamous intraepithelial lesions (HSIL) has been established as $37.7 \%$, and it has been stated that adding colposcopy to cytology only increases this rate to $40 \% .{ }^{[7]}$

Another important finding is that about $30 \%$ of invasive cancers are found in women during regular smear checks (at intervals of less than 3 years). It is the opinion of the authors that smear examinations are not sufficiently accurate. Research has shown false negatives at a rate of $20-45 \%$. It has been recommended that fluid-based cytology should be preferred, since it has a higher sensitivity compared to conventional smear ( $83 \%$ vs $66 \%$ ). ${ }^{[4]}$ The latest fluid-based cytology is now in use at our clinic.

Secondary test used frequently in the diagnosis of LSIL is colposcopy. Jones et al. conducted research on the necessity of colposcopy. As a result of a 5 -year retrospective

Table I. Age distribution of patients with LSIL for whom colposcopic biopsy was performed

\begin{tabular}{lccccc}
\hline Age group (years) & \multicolumn{3}{c}{ Colposcopic biopsy follow-up } & \\
\cline { 2 - 5 } & \multicolumn{2}{c}{ LSIL cases } & \multicolumn{2}{c}{ Biopsy cases } & Biopsy taken-LSIL \\
\cline { 2 - 6 } & $\mathbf{n}$ & $\%$ & $\mathbf{n}$ & $\%$ & $\%$ \\
\hline$<25$ & 12 & 5 & 8 & 7.4 & 66.7 \\
$26-35$ & 88 & 36.7 & 64 & 37.2 & 72.7 \\
$36-45$ & 80 & 33.3 & 64 & 37.2 & 80 \\
$46-55$ & 36 & 15 & 24 & 14 & 66.7 \\
$\geq 56$ & 24 & 10 & 12 & 6.9 & 50 \\
Total & 240 & 100 & 172 & 100 & 71.7 \\
\hline
\end{tabular}

LSIL: Low-grade squamous intraepithelial lesions. 
Table 2. Histology results of patients with LSIL smear according to age group

\begin{tabular}{|c|c|c|c|c|c|c|c|c|c|c|c|c|}
\hline \multirow[t]{3}{*}{ Age group (years) } & \multicolumn{12}{|c|}{ Histological diagnosis } \\
\hline & \multicolumn{2}{|c|}{ Cervicitis } & \multicolumn{2}{|c|}{ CIN-I } & \multicolumn{2}{|c|}{ CIN-II } & \multicolumn{2}{|c|}{ CIN-III } & \multicolumn{2}{|c|}{$\begin{array}{l}\text { Invasive } \\
\text { carcinoma }\end{array}$} & \multicolumn{2}{|c|}{ Age group } \\
\hline & $\mathbf{n}$ & $\%$ & $\mathbf{n}$ & $\%$ & $\mathbf{n}$ & $\%$ & $\mathbf{n}$ & $\%$ & $\mathbf{n}$ & $\%$ & $\mathbf{n}$ & $\%$ \\
\hline$<25$ & 0 & 0 & 4 & 50 & 4 & 50 & 0 & 0 & 0 & 0 & 8 & 4.7 \\
\hline $26-35$ & 4 & 6.3 & 48 & 75 & 8 & 12.5 & 4 & 6.3 & 0 & 0 & 64 & 37.2 \\
\hline $36-45$ & 0 & 0 & 48 & 81.3 & 12 & 18.8 & 4 & 6.3 & 0 & 0 & 64 & 37.2 \\
\hline $46-55$ & 8 & 33.3 & 8 & 33.3 & 0 & 0 & 4 & 16.7 & 4 & 16.7 & 24 & 14 \\
\hline$\geq 56$ & 8 & 66.7 & 0 & 0 & 4 & 33.3 & 0 & 0 & 0 & 0 & 12 & 9.6 \\
\hline Histology (\%) & 20 & 11.6 & 108 & 62.8 & 28 & 16.3 & 12 & 6.8 & 4 & 2.3 & 172 & 100 \\
\hline
\end{tabular}

LSIL: Low-grade squamous intraepithelial lesions. CIN: Cervical intraepithelial neoplasia.

Table 3. Results of LSIL cytologies

\begin{tabular}{|c|c|c|c|c|c|c|c|c|}
\hline & \multicolumn{2}{|c|}{ Cytology } & \multicolumn{2}{|c|}{ Persistent } & \multicolumn{2}{|c|}{ Progression } & \multicolumn{2}{|c|}{ Regression } \\
\hline & $\mathbf{n}$ & $\%$ & $\mathbf{n}$ & $\%$ & $\mathbf{n}$ & $\%$ & $\mathbf{n}$ & $\%$ \\
\hline LSIL & 172 & 100 & 38 & 22 & 16 & 9 & 118 & 68 \\
\hline
\end{tabular}

LSIL: Low-grade squamous intraepithelial lesions.

study, they recorded persistent disease in II of 250 patients; presence of LSIL was detected by colposcopy in only I patient who had not had abnormal smear result. Consequently, they stated that routine colposcopy adds minimal contribution to cytology. Their study included patients with LSIL who were receiving local ablation or excisional treatment. Electrocautery was used for $46 \%$ of these patients, laser ablation for $35 \%$, large loop excision of the transformation zone (LLETZ) for 17\%, and conization for $2 \%$. HSIL was detected in 2 cases. Additional treatment was implemented for 8 of II persistent cases. Spontaneous regression was observed in 3 . Success rate after initial treatment was determined to be $95.6 \% .^{[3]}$ In the present study, persistent disease was found in 38 of 240 patients, and progression was seen in 16.

It has been established that cervical biopsy with colposcopy advances the results of colposcopic examination and provides histological result. It has also been stated that the results of cervical biopsy are related to the area where the biopsy sample is taken. Consequently, it has been expressed that histological examination conducted after transformation zone surgery guarantees diagnostic clarity. ${ }^{[7]}$

Montz and colleagues evaluated 632 patients with atypical squamous cells of undetermined significance (ASCUS) or
LSIL smear results. Patients were followed for at least 9 months with colposcopy or smear carried out once every 3 months. Moderate and severe dysplasia were encountered on first colposcopy in 19\% of patients. While $18.2 \%$ remained the same in the LSIL group, $78.3 \%$ returned to normal and $3.4 \%$ progressed. ${ }^{[8]}$ The present study had similar results. In our study, moderate to severe dysplasia was observed in 40 cases and regression was seen in 118 cases during follow-up visits.

Fallani and colleagues compared biopsy histologies of cases with ASCUS or LSIL cytological diagnosis from colposcopy. They found diagnosis of ASCUS in 358 of 584 women, and 226 received LSIL diagnosis. According to the results, colposcopic examination was recommended for all patients with cytological diagnosis of ASCUS or LSIL. [9] Schiffman et al. reported in an article that I572 LSIL cases had been analyzed as part of ASCUS-LSIL Triage Study (ALTS) study. At the end of 2-year period, more than 63\% of the women would have been referred for colposcopy using any of the cytological or virological strategies that detected $90 \%$ of CIN 3 lesions and cancers. ${ }^{[10]}$

In the present study, dense acetowhite epithelium, mosaicism, punctuation or atypical vascularization were seen in $71.7 \%$ of study participants on colposcopic examinations. 
Biopsies were performed and CIN was revealed histologically in $85.9 \%$ of patients and invasive carcinoma in $2.3 \%$ (Table 2). Accordingly, the sensitivity of colposcopy in this study was determined to be $100 \%$.

Uncertainties remain regarding how follow-up should be conducted for patients with LSIL. Previous studies have shown that using merely colposcopy on follow-up has low sensitivity. ${ }^{[3]}$ It has been shown that $70 \%$ of LSIL lesions regress on their own; however, $10 \%$ progress to HSIL. ${ }^{[1,12]}$ Petry et al. reported $30.2 \%$ CIN 3 and I\% cervical carcinoma in LSIL patients. ${ }^{[13]}$ These rates are compatible with current study research.

As a result of studies looking at how patients respond to treatment, it has been determined that the success rate after LSIL treatment ranges between $85 \%$ and $95 \%{ }^{[8-13]}$ Histological distribution of 172 patients with LSIL cytology from whom biopsy samples were taken in present study was as follows: $11.6 \%$ chronic cervicitis, $62.8 \% \mathrm{CIN}$ I, $16.3 \% \mathrm{CIN} 2,6.8 \% \mathrm{CIN} 3$ and $2.3 \%$ invasive cervical cancer. Persistence was observed in $22 \%(n=38)$ of cases, and progression to HSIL was seen in $9 \%(n=16)$. Regression in smear pathologies took place in $68 \%(n=118)$ of LSIL patients.

As a result of all of these evaluations, it is certain that repetition of Papanicolaou smears is recommended for patients with LSIL. ${ }^{[14]}$ However, it carries the risk of false negativity. A study has noted a $22 \%$ false negative result for CIN 2 and CIN3 in repeated smears right before biopsy. Furthermore, 2 of 6 invasive cervical cancers were missed. ${ }^{[15]}$ The present study results revealed differences between initial smears and follow-up smears of patients whose initial test was not analyzed, possibly due to false negative results.

Information regarding rate low-grade lesions will regress or whether there will be progression or not is inconsistent. Since no test can predict the natural evolution of $\mathrm{CIN}$ beforehand, earliest possible histological diagnosis can be advantageous in terms of early treatment. Moreover, there is a possibility of losing patients to follow-up.

It is of grave importance for patients with low grade abnormal smears to have regular follow-up visits even after colposcopic examination. Just as there can be false negative results from initial colposcopic examination, colposcopy can also be insufficient. In present study, $22 \%$ persistence, $9 \%$ progression, and $68 \%$ regression was observed in LSIL patients.

In cases of low-grade abnormal cytologies, there is a high rate of amelioration in pathology on follow-up. ${ }^{[16]}$ However, it is clinically important to perform colposcopy evaluation of patients with LSIL cytology and conduct biopsy when needed as well as follow-up, due to the possibility of progression in lesions.

\section{Conclusion}

It is critical not to delay histological evaluation of cervical and endocervical area of a patient in whom LSIL has been detected. However, the ideal frequency of follow-up visits and treatment method has not become clear yet. The most important reason for this is that we trust smear examinations with normal result or colposcopic examinations that look normal.

It is the opinion of the authors that new methods in the evaluation of cervical pathologies, such as fluid-based cytology, will decrease false negativity and false positivity and eliminate the current uncertainties.

\section{REFERENCES}

1. Fatih MF, Veli M, Taner M, Nurhan U, Derya T. Evaluation of PapSmear Results of Patients Who Applied to Our Obstetrics and Gynecology Clinic. Okmeydanı Tip Dergisi 2012;28:142-5.

2. Scheungraber C, Kleekamp N, Schneider A. Management of lowgrade squamous intraepithelial lesions of the uterine cervix. Br J Cancer 2004;90:975-8.

3. Jones S, Sykes P, Pather S, Peddie D. Is there a role for colposcopy in the follow-up of treated low grade squamous intraepithelial lesions? Aust N Z J Obstet Gynaecol 2004;44:574-6.

4. Clavel C, Dalstein V, Birembaut P. Stratégies de dépistage des lésions précancéreuses du col del.utérus: cytologie ou test HPV? Revue Francophone des Laboratoires 2008;405:57-65.

5. Kaygusuz EI, Cetiner H, Sahin D. LSIL/ASC-H (LSIL-H) in Cervicovaginal Smear: Histopathological Outcomes and Clinical Significance. Türk Patoloji Derg 2011;27:46-50.

6. Yalti S, Gürbüz B, Bilgiç R, Cakar Y, Eren S. Evaluation of cytologic screening results of the cervix. Int J Gynecol Cancer 2005;15:2924.

7. Mergui JL, Carcopino X, Marchetta J, Gondry J, Boubli L. Modern management of cervical intraepithelial neoplasia: a proposal for a risk assessment method in colposcopic decision-making. J Gynecol Obstet Biol Reprod (Paris) 2010;39:520-8.

8. Montz FJ. Management of high-grade cervical intraepithelial neoplasia and low-grade squamous intraepithelial lesion and potential complications. Clin Obstet Gynecol 2000;43:394-409.

9. Fallani MG, Penna C, Fambrini M, Marchionni M. Cervical cytologic reports of ASCUS and LSIL. Cyto-histological correlation and implication for management. Minerva Ginecol 2002;54:263-9.

10. Schiffman M, Solomon D. Findings to date from the ASCUS-LSIL Triage Study (ALTS). Arch Pathol Lab Med 2003;127:946-9.

11. Holowaty P, Miller AB, Rohan T, To T. Natural history of dysplasia of the uterine cervix. J Natl Cancer Inst 1999;91:252-8.

12. Ostör AG. Natural history of cervical intraepithelial neoplasia: a critical review. Int J Gynecol Pathol 1993;12:186-92.

13. Petry KU, Böhmer G, Iftner T, Davies P, Brummer O, Kühnle H. Factors associated with an increased risk of prevalent and incident grade III cervical intraepithelial neoplasia and invasive cervical cancer among women with Papanicolaou tests classified as grades I or II cervical intraepithelial neoplasia. Am J Obstet Gynecol 2002;186:2834.

14. Noumoff JS. Atypia in cervical cytology as a risk factor for intraepi- 
thelial neoplasia. Am J Obstet Gynecol 1987;156:628-31.

15. Karman RJ, Solomon D. The Bethesta System for reporting cervical/vaginal cytologic diagnoses. 2nd ed. New York: Springer Verlag; 1994.
16. Alanen KW, Elit LM, Molinaro PA, McLachlin CM. Assessment of cytologic follow-up as the recommended management for patients with atypical squamous cells of undetermined significance or low grade squamous intraepithelial lesions. Cancer 1998;84:5-10.

\section{Serviksin Düşük Dereceli İntraepitelyal Lezyonlarının Klinik Önemi: Sekiz Yillik Deneyim}

Amaç: Bu çalışmada, servikal smearlerinde düşük dereceli skuamöz intraepitelyal lezyon (LGSIL) saptanan hastaların izlemleri sonucundaki histolojik tanılarının değerlendirilmesi ve bir tedavi rehberi geliştirilmesi amaçlandı.

Gereç ve Yöntem: Servikal smear incelemesinde LGSIL saptanan 240 gebe olmayan hastanın kolposkopik incelemesi ve gerekli görülenlerde kolposkopi rehberliğinde servikal biyopsi ve endoservikal örnekleme yapıldı. Hastalar üç-dört ay aralıklarla servikal smear kontrolüne alındı.

Bulgular: İki yüz kırk LGSIL saptanan hastanın I08'inde (\%62.8) servikal intraepitelyal neoplazi I (CIN I), 28'inde (\%I6.3) CIN 2, I2'sinde (\%6.8) CIN 3 ve dördünde invazif serviks kanseri saptandı. On iki aylık takiplerinde hastaların 38 'inde (\%22) persistans, 16'sında (\%9) yüksek dereceli displaziye progesyon, II8'inde ise (\%68) regresyon olduğu gözlendi.

Sonuç: Servikal minör anormallikler, düşük dereceli lezyonlara, yüksek dereceli lezyonlara ve hatta serviks kanserine dahi değişebildiği için kolposkopinin doğru tanıya ulaşmada uygun bir yöntem olduğu görüldü. Takipteki en ideal uygulama kolposkopinin smear ile beraber yapılması olarak bulundu.

Anahtar Sözcükler: Düşük dereceli skuamöz intraepitelyal lezyon; kolposkopi; smear. 